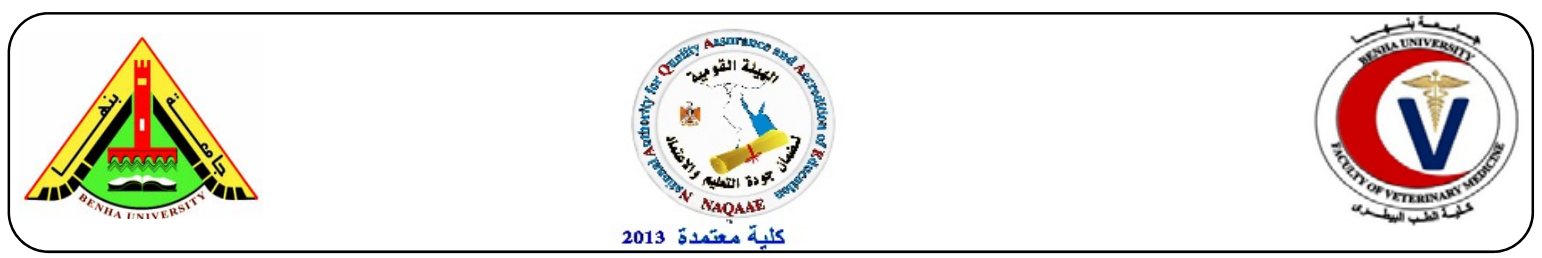

\title{
Prevalence of $E$. coli and detection of virulent genes by multiplex PCR in meat products
}

\author{
Hemmat M. Ibrahim ${ }^{1}$, Mohamed A. Hassan ${ }^{1}$, Reham A. Amin ${ }^{1}$, Nesreen, Z. Eleiwa ${ }^{2}$, Samaa, S. \\ Nadim $^{2}$ \\ ${ }^{1}$ Department of Food Hygiene, Faculty of Veterinary Medicine, Benha University. ${ }^{2}$ Meat hygiene, \\ animal health research institute Tanta Branch. ${ }^{3}$ Department of general medical, Centeral labora- \\ tories, Al-Azhar University.
}

\begin{abstract}
A B S T R A C T
A total of 100 meat products samples of minced meat, kofta, beef burger and sausage ( 25 samples of each), weight of each sample10gm were collected from different shops and supermarkets in Cairo governorate, to be investigated for the presence of $E$. coli and detection of virulent genes by modern technique (PCR). The obtained results indicated that the incidence of $E$. coli isolated from the examined samples were (4)16\%, (7)28\%, (6)24\% and (11)44\% of minced meat, kofta, beef burger and sausage, respectively. Actually E. coli strains isolated from 18 positive E.coli were 9 strains $O_{26}, O_{55}: H_{7}, O_{103}$, $\mathrm{O}_{111}: H_{4}, \mathrm{O}_{114}: \mathrm{H}_{21}, \mathrm{O}_{119}: \mathrm{H}_{6}, \mathrm{O}_{124}, \mathrm{O}_{125}: \mathrm{H}_{21}$ and $\mathrm{O}_{128}: \mathrm{H}_{2}$. These isolated strains were investigated by using Multiplex PCR to detect presence of virulent genes (stx1, stx2 and eaeA) in each isolated strain. The results obtained reported that E. coli $O_{26} \& O_{111}$ posses (3) genes stx1, st $x 2$ and eaeA genes, E.coli $O_{103}$, $O_{119} \& O_{128}$ carry (2) genes st $x 1$ and stx2, E. coli $O_{55}$ carry (2) genes st $x 1$ and eaeA genes, E.coli $O_{125}$ carry (2) genes stx2 and eaeA genes, E. coli $O_{114}$ posses (1) gene stx1gene. While virulence genes were not detected in E. coli $O_{124}$.
\end{abstract}

Keywords: E.coli, Meat Products, PCR.

(http://www.bvmi.bu.edu.eg)

(BVMJ-29(2): 268-273, 2015)

\section{INTRODUCTION}

$\mathrm{D}$ uring the last decade, the increase of human population in relative to the great development in human life caused a great demand of easily prepared meals contained high level of animal protein. However, meat products are generally excellent sources of protein containing a good balance of the essential amino acids and having a high biological value (Biesalski, 2005). Food borne diseases remain a major problem and one of public health concern. Epidemiological data show an increasing incidence of infectious diarrhea (Osservasalute, 2008). It is reported that large number of human illness outbreaks have been traced worldwide during the past 23 years due to consumption of under-cooked ground beef and other beef products contaminated with Shiga toxinproducing E. coli (STEC). Because most STEC outbreaks in the epidemiological studies have focused on the prevalence of this serotype in beef cattle worldwide, however, additional STEC serotypes (e.g., members of the $\mathrm{O}_{26}, \mathrm{O}_{91}, \mathrm{O}_{103}, \mathrm{O}_{111}, \mathrm{O}_{118}$, $\mathrm{O}_{145}$ and $\mathrm{O}_{166}$ serogroups) have been isolated from beef and caused human illnesses ranging from bloody diarrhea and hemorrhagic colitis to the life-threatening hemolytic uremic syndrome (HUS) (Little et al., 2008). Application of multiplex PCR for detection of non- $\mathrm{O}_{157}: \mathrm{H}_{7} \quad$ STEC virulence genes as (stx1, stx2, eae, hly, etpD, katP6) not only improve the detection 
efficiency but also increase the accuracy and mentioned that traditional detection approaches for non- $\mathrm{O}_{157}$ STEC are both time and labour consuming in diseases surveillance (Wang et al., 2013).

Therefore, the present study was planned out to throw out light on: Conventional recovery methods, to detect prevalence of E.cloi in examined meat products. Bacteriological and serological identification of the isolates. Molecular characterization of E.cloi strains using Polymerase chain reaction (PCR) for detection of virulent genes of isolated E.cloi strains.

\section{MATERIAL AND METHODS}

\subsection{Collection of samples}

One hundred random samples of meat products represented by minced meat, kofta, beef burger and sausage (25of each), sample weight $10 \mathrm{gm}$ were collected from different supermarkets and from retail stores in Cairo governorate. The collected samples were aseptically collected in sterile polyethylene bags. All samples were examined bacteriological for detection of E.cloi.

\subsection{Isolation and identification E.cloi}

The technique recommended by (APHA, 1992) by using Eosin Methyline Blue (EMB) agar media. Suspected colonies for E. coli were morphologically and biochemically identified.

\subsection{Serotyping of E.cloi}

E. coli isolates were serologically identified according to (Kok et al., 1996) by using rapid diagnostic $E$. coli antisera sets (DENKA SEIKEN Co., Japan) for diagnosis of the enteropathogenic types.

\subsection{In-Vitro anti-microbial sensitivity test}

The isolated E. coli strains were subjected to antimicrobial susceptibility was tested by the single diffusion method according to (Mary and Usha, 2013).
2.5. Detection of Virulence genes of isolated E. Coli strains by mutiplex PCR

Application of PCR for identification of shiga toxins (stx1 \& stx2) and intimin (eaeA) genes of E. coli was performed essentially by using Primers (Pharmacia Biotech) as shown in the table (1).

Table (1): Primers sequences, target genes and amplicon size of the used genes

\begin{tabular}{|c|c|c|c|}
\hline Target gene & Oiligonucleotide sequence $\left(j^{\prime} \rightarrow 3\right)$ & $\begin{array}{c}\text { Product } \\
(6 p p)\end{array}$ & References \\
\hline $\begin{array}{l}\operatorname{stxl}(\mathbb{R}) \\
\operatorname{Stxl}(\mathbb{R})\end{array}$ & $\begin{array}{l}\text { 5'ACACTGGATGATCTCAGTGG'3 } \\
\text { 5'CTGAATCCCCCTCCATATIG' }\end{array}$ & 61.4 & $\frac{\text { Dhannshree and Nally }}{2008)}$ \\
\hline $\operatorname{Stx} 2(\mathrm{R})$ & 5'CCATGACAACGGACAGCAGTI'3 & & (Dhanshiree and Mallix \\
\hline $\operatorname{Stx} 2(\mathbb{R})$ & 5'CCTGTCAACTGAGCAGCACTTIG 3 & $1 / 9$ & 2008) \\
\hline $\begin{array}{l}\text { exeA (R) } \\
\operatorname{ereat}(R)\end{array}$ & $\begin{array}{l}\text { 5'GTGGCGAATACTGGCGAGACT'3 } \\
\text { 5'CCCCATTCTITTCACCGTCG'3 }\end{array}$ & 890 & (Jeshreen et a., 2013) \\
\hline
\end{tabular}

\section{RESULTS}

It is evident from the results recorded in table (2) that that the incidence of E. coli in minced meat, kofta, beef burger and sausage were $4(16 \%), 7(28 \%), 6(24 \%)$ and $11(44 \%)$, respectively. Table (3) show the percentage of the accepted examined meat products according to ESS (2005) of E. coli, acceptable samples were $84 \%, 72 \%$, $76 \%, 56 \%$ in minced meat, kofta, beef burger and sausage, respectively.

Table (2): Incidence of isolated E.coli from examined meat product samples

\begin{tabular}{lcc}
\hline products & $\begin{array}{c}\text { Number } \\
\text { of } \\
+ \text { Ve isolates }\end{array}$ & $\%$ \\
\hline Minced meat $(\mathrm{n}=25)$ & 4 & 16 \\
Kofta $(\mathrm{n}=25)$ & 7 & 28 \\
Beef burger $(\mathrm{n}=25)$ & 6 & 24 \\
Sausage $(\mathrm{n}=25)$ & 11 & 44 \\
\hline
\end{tabular}

Results achieved in table (4) show the serological identification of $E$. coli isolated from examined meat product samples, were belonged to the following serotypes E.coli $\mathrm{O}_{26}, \mathrm{O}_{55}, \mathrm{O}_{103}, \mathrm{O}_{111}, \mathrm{O}_{114}, \mathrm{O}_{119}, \mathrm{O}_{124}, \mathrm{O}_{125}$, $\mathrm{O}_{128 .}$. 
Table (3): Acceptability of the examined samples of meat products based on their contamination with E.coli according to ESS (2005)

\begin{tabular}{lcc}
\hline products & $\begin{array}{c}\text { Number } \\
\text { of } \\
\text { isolates }\end{array}$ & $\%$ \\
\hline Minced meat $(\mathrm{n}=25)$ & 21 & 84 \\
Kofta $(\mathrm{n}=25)$ & 18 & 72 \\
Beef burger $(\mathrm{n}=25)$ & 19 & 76 \\
Sausage $(\mathrm{n}=25)$ & 14 & 56 \\
\hline
\end{tabular}

Table (4): Incidence of pathogenic E. coli serotypes in examined meat products

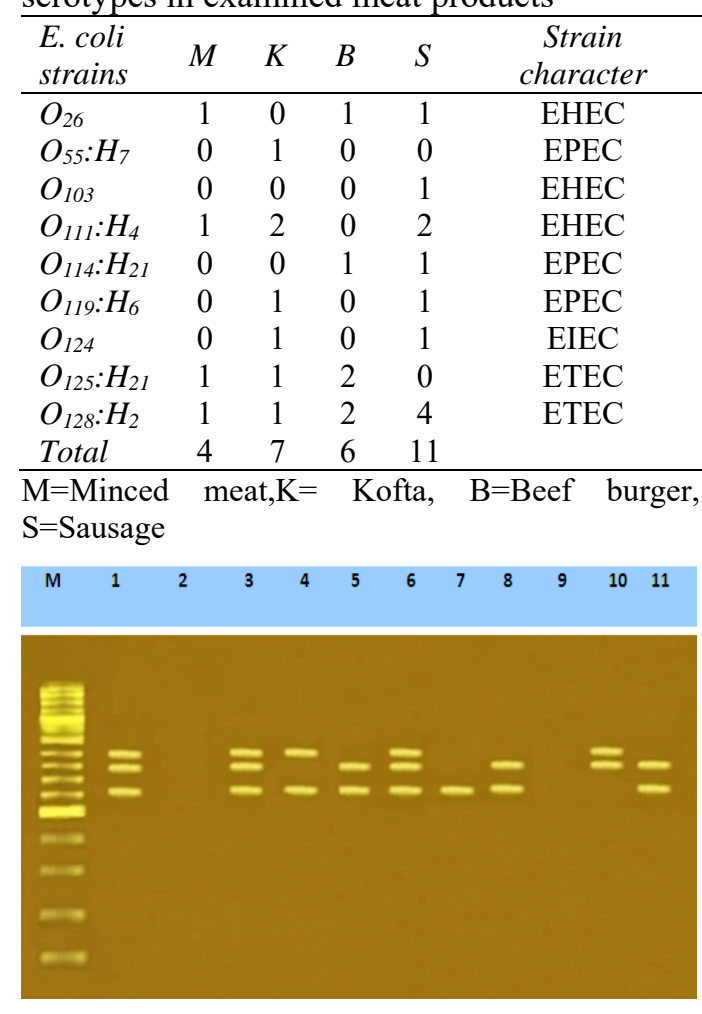

Photo (1): Agarose gel electrophoresis of multiplex PCR of stx1 (614 bp), stx2 (779 bp) and eaeA (890 bp) genes for characterization of Entero - pathogenic E. coli. Lane M: 100 bp ladder as molecular size DNA marker. Lane 1: Control positive for stx1, stx2 and eaeA genes. Lane 2: Control negative for stx1, stx2 and eaeA genes. Lane $3 \& 6$ (E. coli $\mathrm{O} 26$ \& O111): Positive strains for stx 1 , stx 2 and eaeA genes. Lane 4 (E. coli O55): Positive strain for stx 1 and eaeA genes. Lane 5, 8 \&11 (E. coli O103, O119\& O128): Positive strains for stx 1 and $s t x 2$ genes. Lane 7 (E. coli O114): Positive strain for stx1 genes. Lane 9 (E. coli O124): Negative strain for stx1, stx2 and eaeA genes. Lane 10 (E. coli O125): Positive strains for stx2 and eaeA genes
Photo (1) revealed that 9 E.coli strains investigated by multiplex PCR to detect presence of virulence genes stx 1 , st $x 2$ and intimin (eaeA). From recorded results found that E. coli $O_{26} \& O_{111}$ posses (3) genes stx1, stx2 and eaeA genes, E. coli $O_{103}, O_{119} \& O_{128}$ carry (2) genes stx1and stx2, E. coli $\mathrm{O}_{55}$ carry (2) genes stx1and eaeA genes, E. coli $O_{125}$ carry (2) genes stx2 and eaeA genes, E. coli $O_{114}$ posses (1) gene stx1gene, while $E$. coli $\mathrm{O}_{124}$ carry no genes.

\section{DISCUSSION}

The presence of E. coli in contaminated food products is commonly attributed to fecal contamination when they are improperly handled and/or when inactivation treatments fail. The adaptation of $E$. coli at low $\mathrm{pH}$ and $\mathrm{a}_{\mathrm{w}}$ levels can vary at different temperatures depending on the serotype (Valero et al., 2010).

Shiga toxin (stx) producing E. coli (STEC) contamination in food and water is one of the most recognized concerns and a major financial burden in human hygiene control worldwide. Rapid and highly reliable methods of detecting and identifying STEC causing gastroenteric illnesses are crucial to prevent food borne outbreaks. A number of tests have been developed and commercialized to detect STEC using molecular microbiology techniques. Most of these are designed to identify virulence factors such as Shiga toxin and intimin as well as E.coli $\mathrm{O}$ and $\mathrm{H}$ antigen serotype specific genes. In order to screen pathogenic STEC without relying on $\mathrm{O}: \mathrm{H}$ serotyping, we developed a rapid detection and genotyping assay for STEC virulence genes using a PCR for detection of major virulence genes, Shiga toxin 1 and 2 (stx1 and stx2), intimin (eae) (Goji et al., 2015).

The incidence of $E$. coli in (Table1) reveled that minced beef was $16 \%$ which is nearly similar to results obtained by (Barlow et al., 2006) and (Filliol et al., 2008) which were $16 \%$ and $17 \%$, respectively. On the other 
hand higher figure obtained by El-Gohary, 1993\& Hugo et al., 2012 \& Zakarya and Fouad 2013 which were $75 \%, 38.1 \%$, and $25 \%$, respectively.

In kofta the incidence of E. coli was $28 \%$ the results is nearly similar to that reported by Torky (2004), 30\%, higher results were obtained by Abdalla and Hassan (2000), $40 \%$ while lower result obtained by El-Sherif (2009) 10\%. The incidence of $E$. coli in beef burger was $24 \%$ nearly similar results obtained by Aouf (2001) 30\%, while lower results recorded by Ahmed (1992) and El- Sherif (2009) were 6.6\% and 10\%, higher results reported by (Fathi et al.,1994) and El-Mossalami (2003) were $77.78 \%$ and $35 \%$, respectively while in sausage the incidence of $E$. coli was $44 \%$ these result nearly similar to results obtained by ElMossalami (2003) 40\%. On the other hand higher results obtained by El-Gohary (1993) with percentage 78\%. Lower figure obtained by Ahmed (1992) and (Zakarya and Fouad, 2013)16.6\%, and 15\%, respectively.

Presence of E. coli in meat products were unaccepted and hazard on consumer health also disagreed with ESS (Egyptian standard specification) of such meat products and indicates inadequate sanitary conditions during stages of manufacturing, dirty equipment and improper handling. (Table 2) show percentage of the accepted examined meat products according to ESS (2005) of E. coli.

The serotypes of E. coli isolated in this study as shown in (table3) were 9 E. coli strains belonged to following serotypes: $\mathrm{O}_{26}, \mathrm{O}_{55}, \mathrm{O}_{103}, \mathrm{O}_{111}, \mathrm{O}_{114}, \mathrm{O}_{119}$, $\mathrm{O}_{124}, \mathrm{O}_{125}, \mathrm{O}_{128}$.

PCR based methods, as multiplex PCR is very useful as it allows the simultaneous detection of several pathogens by introducing different primers to amplify DNA regions coding for specific genes of each bacterial strain targeted (Touron et al., 2005).

So these $9 E$. coli strains were investigated by using multiplex PCR to detect presence of virulence genes stx 1 , stx 2 and intimin
(eaeA). From recorded results found that $E$. coli $O_{26} \& O_{111}$ posses (3) genes stx1, st $x 2$ and eaeA genes, E. coli $\mathrm{O}_{103}, \mathrm{O}_{119} \& \mathrm{O}_{128}$ carry (2) genes stx1and stx2, E. coli $O_{55}$ carry (2) genes stx1and eaeA genes, E. coli $O_{125}$ carry (2) genes $s t x 2$ and eaeA genes, $E$. coli $O_{114}$ posses (1) gene stx1gene, while $E$. coli $\mathrm{O}_{124}$ carry no genes. The strains which were positive for eaeA gene which encodes intimin, an important binding protein of pathogenic STEC as E. coli $\mathrm{O}_{26}$, $O_{111}, O_{55}$ and $O_{125}$ more virulent than other strains not carry this gene and considered more toxigenic and hazardous to consumer health.

Applying Modern technique as PCR based detection of Shiga toxin-producing $E$. coli (STEC) in a routine microbiology laboratory over 16 years, molecular characterization of strains.

Shiga toxin-producing E.coli (STEC) is a heterogeneous group of bacteria causing disease ranging from asymptomatic carriage and mild infection to hemolytic uremic syndrome (HUS). Characterize STEC detected by use of PCR for detection of stx1, stx2 and eae genes from 996 through 2011. STEC isolates were characterized with respect to serogroup or serotype, (Haugum et al., 2014).

\section{REFERENCES}

Abdallah, W., Hassan, A.A. 2000. Sanitary status of some ready to eat meat meals in Cairo and Giza Governorates. J. Egypt. Vet. Med., Assuit, 60(7): 95.

Ahmed, N.M. 1992. Incidence and occurrence of Salmonellae and E. coli organisms in packed meat products. M. V. Sc. (Meat Hygiene) Fac. Vet. Med., Assuit University.

American public Health Association "APHA"1992. Compendium of methods for microbiological examination of foods. $3^{\text {rd }} \mathrm{Ed}$. Academic Press Washington, DC, U.S.A.

Aouf, Gehan. 2001. Microorganisms of sanitary importance in some meat 
products and their additives. Ph.D. Thesis. (Meat Hygiene) Fac. Vet. Med. Cairo. Univ.

Barlow, R.S., Gobius, K. S., Desmarchelier, P. M. 2006. Shiga toxin-producing E. coli in ground beef and lamb cuts: results of a one-years study. Int. J. Food Microbiol. 111(1): 1-5

Biesalski, H.K. 2005. Meat as a component of a healthy diet - are there any risks or benefits if meat is avoided in the diet? Meat Sci., 70:509-524.

Dhanashree, B., Mallya, S. 2008. Detection of Shiga-toxigenic Escherichia coli (STEC) in diarrhoeagenic stool and meat samples in Mangalore, India. Indian J. Med. Res., 128: 271-277.

Egyptian Standards specification (ESS) 2005. For beef burger No. 1688.

Egyptian Standards specification (ESS) 2005. For minced meat No. 1694.

Egyptian Standards specification (ESS) 2005. For sausage No. 1972.

Egyptian Standards specification (ESS) 2005. For beef Kofta No. 1973.

El-Gohary, A.H. 1993. Sausage and minced meat as a source of food poisoning microorganisms to man. Assiut, Vet. Med. J. 30(59) :77-98.

El-Mossalami, E.I.K. 2003. Risk assessment of ready prepared meat products. Ph. D. Thesis, (Meat Hygiene), Fac. Vet. Med., Cairo. Univ. Egypt.

El-Sherif, A.M. 2009. Different serotypes of E. coli and Salmonellae in some Meat Products and their behavior during different heat treatments and cold storage. Ph. D. Thesis Fac. Vet. Med. Cairo. Univ. Egypt.

Fathi, S.; EL-Kateib, T., Mostafa, S., Hassanin, K. 1994. Salmonella and Enteropathogenic Escherichia coli in some locally manufactured meat products. Assiut Vet Med. J., 31: 190199.

Filliol, I., Hassar, M., Cohen, N., Karraouan, B., Badri, S., Carle, I., Brahim, H., Karib, H. 2008. Microbial Quality Control of Raw Ground Beef and Fresh Sausage in Casablanca (Morocco). J. Environ Health. 2008 Nov; 71(4):51-5.

Goji, N., Mathews, A., Huszczynski, G., Laing, C.R., Gannon, V.P., Graham, M.R. 2015. A new pyrosequencing assay for rapid detection and genotyping of Shiga toxin, intimin and O157-specific $\mathrm{rfbE}$ genes of Escherichia coli. J. Microbiol Methods., 109:167-179.

Haugum, K., Brandal, L.T., Lindstedt, B.A., Wester, A.L. 2014. PCR based detection of Shiga toxin-producing Escherichia coli (STEC) in a routine microbiology laboratory over 16 years: molecular characterization of strains. J. Clin Microbiol. pii: JCM.00453-14.

Hugo, A., Hugo, C., Charimba, G. 2012. The incidence of diarrhea genic Escherichia coli in minced beef and boerewors. Food Research Inter., 47(2): 353-358.

Jeshveen, S., Chai, L., Pui, C., Son, R. 2013. Optimization of multiplex PCR conditions for rapid detection of Escherichia coli O157:H7 virulence genes. Int. Food Res. J. 19(2): 461466.

Kok, T., Worswich, D., Gowans, E.1996. Some serological techniques for microbial and viral infections. Practical Medical Microbiology (Collee, J.; Fraser, A.; Marmion, B., Simmons, A., eds), 14th ed., Edinburgh, Churchill Livingstone, UK.

Little, C.L., Richardson, J.F., Owen, R.J., Pinna, E.D., Threlfall, E.J. 2008. Campylobacter and Salmonella in raw red meats in the United Kingdom: prevalence, characterization and antimicrobial resistance pattern, 2003-2005. Food Microbiol., 25(3): 538-543.

Mary, C., Usha, M. 2013.Incidences of multi-drug resistance Escherichia coli isolates in Panipuri sold in Bangalore. Int. J. Food Res., 20(2): 1007-1009. 
Osservasalute. 2008. Health status and quality of the Italian regions. Report 2008: $175-177$.

Torky, A.A.S. 2004. Trials for inhibition of some food poisoning microorganisms in meat products. Ph. D. Thesis. (Meat Hygiene) Fac. Vet. Med., Cairo Univ. Egypt.

Touron, A., Berthe, T., Pawlak, B., Petit, F. 2005. Detection of Salmonella in environmental water and sediment by a nested-multiplex polymerase chain reaction assay. Res Microbiol., 156:541-53.

Valero, A., Rodrígueza, M., Carrascoa, E., Pérez-Rodrígueza, F., GarcíaGimenoa, R.M., Zurera, G. 2010. Studying the growth boundary and subsequent time to growth of pathogenic Escherichia coli serotypes by turbidity measurements. Food Microbiol, 27(6): 819- 828.

Wang, X.G., Zhang, Y.H., Chen, X.H., Luo, L.F., Liu, Y., Liu, J.Q., Song, C.P., Chen G.Q. 2013. Establishment and application of multiplex PCR for non-O157: H7 STEC virulence genes detection. Zhonghua Shi Yan He Lin Chuang Bing Du Xue Za Zhi. (Article in Chinese)., 27(5):388-391.

Zakarya, E. M., Fouad, M. 2013. Comparison between traditional methods and real time PCR for detection of $\mathrm{E}$. coli in bovine meat products. Assiut Vet. Med. J., 59(138). 